Technical Memorandum 33-714

\title{
Apogee Motor Rocketry Reliability Improvements
}

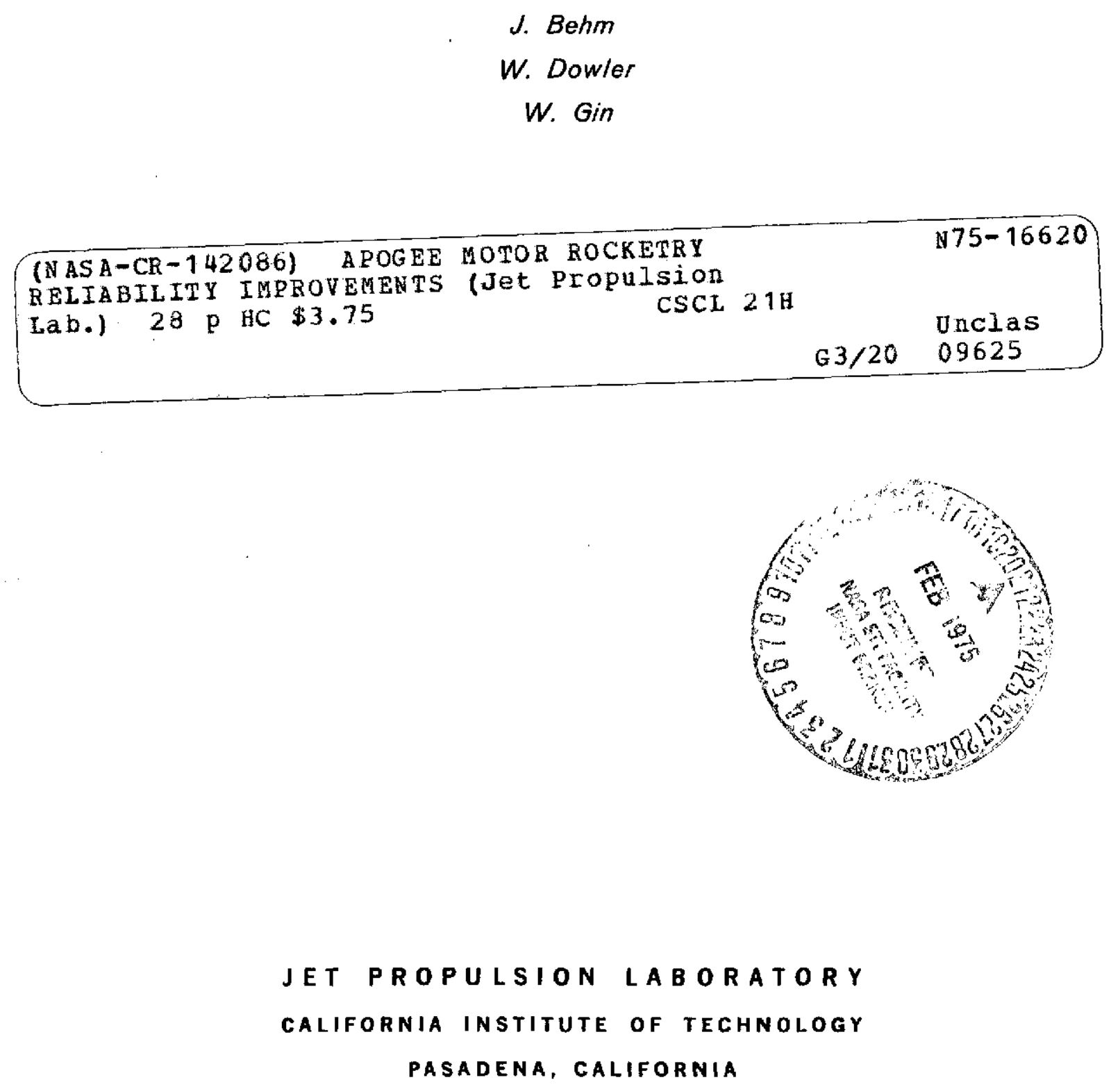

December 15, 1974 
Prepared Under Contract No. NAS 7-100

National Aeronautics and Space Administration 


\section{PREFACE}

The work described in this report was performed by the Propulsion Division of the Jet Propulsion Laboratory. 
I. Introduction ....................... 1

II. Background . . . . . . . . . . . . . . . . 2

III. Design Options to Enhance Functional Reliability . . . . . . . 2

IV. Testing and Inspection Practices . . . . . . . . . . . 3

A. Squibs ....................... 3

B. Motor Assembly Testing. . . . . . . . . . . . . 4

C. Motor Assembly Inspections . . . . . . . . . . . . 6

D. Motor Shelf Life Predictions . . . . . . . . . . . . 6

V. Flight Failure Survey Studies . . . . . . . . . . . . . 7

A. System Effects Study . . . . . . . . . . . . 8

B. Apogee Motor Reliability Study . . . . . . . . . . 9

VI. Diagnostic Instrumentation ................. 10

VII. Concluding Recommendations . . . . . . . . . . . . 11

Definition of Abbreviations . . . . . . . . . . . . . . 12

References . . . . . . . . . . . . . . . . . . . 13

\section{TAB LES}

1. Estimated apogee motor use through 1990 . . . . . . 14

2. Apogee motor reliability design options . . . . . . . 15

3. Selected flight failures ............... 16

4. Solid motor diagnostic instrumentation characteristics................ 16

5. Functional and unit characteristics of candidate designs.................... 17

6. Candidate design properties............ 18

\section{PRECEDING PAGE BLANK NOT FLLMED}


FIGURES

1. ATS a pogee motor assembly ............ 19

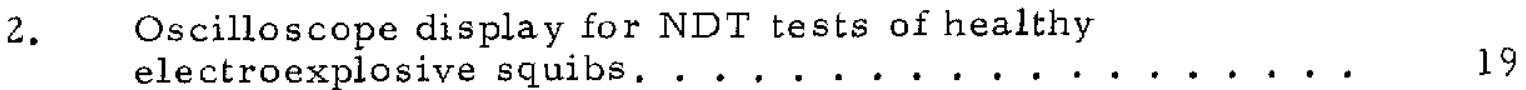

3. Conceptual design of hardened package ......... 20 


\begin{abstract}
Since 1963, solid propellant apogee motors have been placing satellites into geosynchronous orbits. Major technological breakthroughs are not required to satisfy future mission requirements; however, there is a need to improve reliability to enhance cost effectiveness. Several management test options are discussed. A summary of results and conclusions derived from review of missions, where failure of a solid motor was inferred, and correlation of system factors with failures are reported. Highlights of a solid motor diagnostic instrumentation study are presented. Finally, recommendations are provided for areas of future apogee motor upgrade, which will increase project cost effectiveness by reducing the potential for future flight failures.
\end{abstract}




\section{INTRODUCTION}

Apogee rocket motors containing solid propellant have been used routinely to boost communications satellites into circular orbits at geosynchronous altitudes for over a decade since the first such satellite. The NASA Syncom was launched in 1963. The compactness and good performance of solid propellant rocket motors made them ideal for this application of a single, burn-to-completion, spin-stabilized maneuver to provide the velocity increment necessary to place the satellite at the proper altitude. A complete listing of the U.S. unclassified communications satellite programs, including the identification of the apogee rocket motor used, has been published by the AIAA (Ref. 1). The list shows 20 motors having been flown from February 1963 through June 1972.

During this past decade, progressively larger and higher performance apogee rocket motors have been supplied by the U.S. solid propulsion indus try for this application to communication satellites. The first motor ever designed and developed for this application was the NASA-Jet Propulsion Laboratory (JPL) Syncom apogee motor (Ref, 2). Next came the series of Aerojet Solid Propulsion Company (SVMs) (Ref, 3). A recent design and development of a communications satellite apogee motor is being accom plished by the Thiokol Chemical Corporation, Elkton Division, for the joint U.S. /Canadian Communications Technology Satellite (Ref. 4).

Another decade from now, however, the U.S. is expected to have the NASA Space Shuttle and IUS operational. At that time, very large communications satellites are expected to be delivered to low Earth orbit by the Shuttle and transferred to geosynchronous orbit by the IUS. Until then, solid propellant apogee rocket motors will continue to be the implementation mode of geosynchronous orbit insertion. These motors are typically nestled in the satellite and dominate the satellite separated mass by usually accounting for half its total mass. Being a nonredundant.element of the satellite, the motor reliability is crucial. Although "breakthroughs' in the technology of apogee motors appear not to be required by communication satellite mission designs, there have been frequent demands to improve their reliability in order to increase mission cost effectiveness.

Recently, in order to gain knowledge to enhance motor reliability for future missions, JPL directed and sponsored the review of several 
spacecraft and satellite applications of the general class of solid propellant motors in which there was an evident motor failure or a spacecraft failure which occurred during the firing of the motor. An audit of contemporary design and development practices and philosophies was performed, and a. generalized failure mode analysis was conducted. Concurrently, a companion study examined possible correlations between system factors (such as storage, handling, and environmental effects) and service failures of this class of motor; another study developed conceptual designs of on-board motor diagnostic instrumentation packages. The results of these studies are presented below.

\section{BACKGROUND}

Since the apogee maneuver is so vital to the mission, each Flight Project Office must gain confidence in the functional reliability of the particular motor being used. Funding constraints in recent years, the limited number of launches within each flight program, and the "one-shot" nature of most solid rocket components result in qualifying each new apogee motor design based on a very limited number of development and qualification motor firings. Hence, functional reliability cannot be physically demonstrated on a large statistical sample size. It is the refore frequently necessary to rely heavily on the prior experience of the rocket motor supplier and the similarity of the new motor design to previous successful designs.

A survey was made in 1972 of expected future utilization of apogee motors for geosynchronous missions. As reflected in Table 1 (Ref. 5), approximately 74 flights are expected between 1975 and 1980. This level of expected flight activity is strong justification to re-examine options available for upgrading future apogee solid propellant motors by enhancing functional reliability.

\section{DESIGN OPTIONS TO ENHANCE FUNCTIONAI, RELIABILITY}

Table 2 outlines the primary options available to enhance reliability. Figure 1 illustrates a typical apogee motor configuration (the motor used in the NASA ATS Program) (Ref. 6). Only limited functional reliability improvements can be achieved through the utilization of conventional 
redundancy techniques. Redundant rocket igniter squibs or equivalent initiators are almost universally provided in the design of each motor. Some motor designs incorporate dual (redundant) igniter assemblies, either one of which is capable of successfully initiating propellant combustion of the main motor grain. Motors with dual igniters are designed to tolerate higher main chamber pressurization rates created by simultaneous discharge from both units. All remaining major motor components including the motor chamber, chamber insulator, propellant grain, relief boots, and nozzle assembly form a highly integrated and interacting combination of single (nonredundant) components, each of which must be capable of delivering its own unique function. The motor designer must therefore insure that adequate structural and the rmal stress margins are provided for each of these components. Because of the highly interactive nature of these components, care must be exercised, through experience and direct testing, to insure that both interface compatibility and functional performance compatibility exist. between individual motor elements. The ATS (Ref. 6) nozzle design (Fig. 1) reflects a JPL design philosophy of minimizing both the number of different materials and the number of parts and physical material interfaces in. order to reduce complexity and interface problems and enhance flight reliability.

\section{TESTING AND INSPECTION PRACTICES}

Volumes have been written on testing and inspection practices that can and do contribute strongly to establishing ultimate reliability and confidence in the total flight rocket motor assembly. Only several major testing aspects will be discussed herein.

\section{A. SQUIBS}

Significantly larger test sample sizes are conventionally used to verify the quality of rocket motor squibs as compared to the number of main motor development and qualification program firings. Bruceton tests using 30 to 50 or more squibs provide a statistical means of predicting all-fire and no-fire current levels. Present 1 amp-l watt no-fire safety requirements can be verified with the Bruceton test where new or modified squib designs are involved. Requalification of new squib lots is frequently imposed on flight missions where high reliability is required. As many as 50 to 100 
squibs may be used in the requalification process. The squib testing techniques noted above are normally destructive in nature and can only provide an indication of the probable number of squibs remaining which may fail to function. This approach cannot identify specifically which of the remaining flight squibs are most likely to fail.

A new and more sophisticated NDT technique has recently been developed for evaluating the quality of flight squibs relative to the bridgewire/explosive/header interface which is judged to be the most critical portion of a typical EED (Ref. 7). Two complementary testing procedures and apparatus have been used to display the electrothermal response of the EED. The first procedure is known as the transient pulse test. A single short transient current pulse is applied to the squib bridgewire, and the characteristic temperature rise, as measured indirectly on a Wheatstone bridge, is displayed on an oscilloscope. A second technique, known as the electrothermal follow test, is accomplished by supplying a steady-state $10-\mathrm{Hz}$ sinusoidal current to the bridgewire, which again forms one leg of a Wheatstone bridge circuit. Resulting bridgewire temperature excursions can be controlled and the bridgewire signal displayed on an oscilloscope; the cyclic pulse produces a Lissajous response. Figure 2 illustrates typical oscilloscope traces for each of these techniques. In each of these tests, the current pulse is maintained at a low level such that the squib is not degraded. In each case, abnormal heating rise times or abnormal heat dissipation as indicated on the oscilloscope are indicative of possible squib fault mechanisms. Fault mechanisms which are detectable include: (1) imperfections in bridgewire cross section; (2) poor bridgewire to pin welds; or (3) loss of intimate contact between bridgewire and the explosive charge. These NDT inspection techniques were first used on JPL flight squibs starting with Mariner 1969.

\section{B. MOTOR ASSEMBLY TESTING}

As indicated previously, most communications satellite programs involve a relatively small number of spacecraft launches, hence the tendency to limit the size of the development and qualification program for each new apogee motor design to minimize program costs. Development and qualification motor firing programs in recent years typically range from a low of 2 or 3 to perhaps as many as 7 or 8 . In some programs, the earlier 
development motors tested may differ from the final qualification configuration in some significant aspect. Therefore, the number of "all-up" motor tests upon which the motor is qualified can be, and usually is, quite small. Qualification of new apogee motor designs using very small sample lots cannot provide significant confidence. The only other alternative is to verify the real motor margins by testing to failure. Design margins testing is most effective when the failure occurs at the predicted limit thus verifying not only the design but the analysis which led to that design. If design margins can be shown to be large relative to service requirements, one or two test points are sufficient to be convincing. The motor case hydroburst is the best historical example.

During the recent fully case-bonded end burning motor program (Ref. 8) at JPL in which unconventional features could lead to unreliability, margin testing techniques were successfully applied such that all demonstration motor static firings were successful. In order to accomplish this in today's $100 \%$ success-oriented climate, one is faced with the dilemma of being conservative so as not to have a failure and the need to verify the margins incorporated and inherent in the design. This dilemma can be overcome by adopting a philosophy of evaluating critical design features with testing of margins at limit loads, during which failures can be expected and will be accepted. As a result, much more can be learned about the motor design from a test to failure than from a success test, and unneeded conservatism cań be eliminated so as to provide an acceptably reliable motor with increased delivered performance.

Some motor failure modes are more amenable to margins testing implementation and have less cost impact than others. It is therefore important to be selective regarding which design margins should be verified. In some cases it is not necessary that the test failure occur during a static test firing. A survey made recently of a number of prime contractor and program office users of apogee motors or upper stage rocket motors confirmed that propellant-to-insulator case bond failure and grain center bore cracking appear to be two of the most common problem areas. However, each motor design may be somewhat unique and must therefore be assessed by reviewing past problems associated with prior motors of similar design. 


\section{MOTOR ASSEMBLY INSPECTIONS}

Radiographic NDT inspection techniques continue to be a prime standard for final inspection and evaluation of the motor grain quality to insure acceptability for flight. The ability to detect small fine line cracks in the main grain is somewhat limited. The ability to consistently detect propellant-to-insulator case bond failures, where the gap is small or zero, constitutes an even more significant problem area for many flight programs. Propellant case bund separation fault detection can be improved markedily if the radiographic inspection is made while the motor is pressurized or conditioned at its low-temperature design limit. Case bond separation gaps normally increase because of the thermal contraction of the grain relative to the insulator/chamber at lower temperatures, hence they become more detectable. Should bond separation occur between the propellant and the surface of the grain relief boot, low-temperature X-ray procedures will be less effective since the boot is free to follow the thermal contraction of the grain.

\section{MOTOR SHELF LIFE PREDICTIONS}

During early apogee motor development programs dating back some years, it was common practice to include several flight motors in each program for the primary purpose of verifying motor shelf life. These units were normally placed in ground storage and a motor was withdrawn periodically, inspected, and test-fired to demonstrate ballistic performance and functional reliability. The schedule match between motor fabrication and final flight usage was such that a 1 - to 2 -year shelf life was normally sufficient. Primarily because of the success of current satellites to extend their useful life in space and a desire to have the capability of replacing an operational satellite at any given time, apogee motor shelf life requirements have been extended to 3 to 5 years. However, these life requirements are rarely verified by storage and subsequent firing of full-scale flight motors. The ability of the motor to remain flight serviceable throughout the required shelf life period is usually predicated on a general knowledge of the aging characteristics of the specific propellant formulation concerned and, additionally, on motor storage firing results which may have been obtained several motor generations prior to the current design. 
The.reliable shelf life of any apogee or upper-stage solid rocket motor is highly dependent on (l) the post-cure ambient curing characteristics of the propellant, (2) the basic chemical stability of the propellant and insulation system formulation being considered, (3) whether plasticizers are used in the formulation and/or the insulation, (4) the true structural design margins (primarily of the grain), and (5) the actual storage, transportation, and handling environments the motor is exposed to prior to flight.

There is some limited evidence that shelf life greatly in excess of the current 5-year requirement is possible. JPL has successfully test-fired a Syncom apogee motor under simulated altitude conditions after 7-1/2 years of ambient storage (Ref. 9). No degradations in ballistic performance or inert hardware were observed.

A new research program has recently been initiated at Thiokol Chemical Corporation, Elkton, Maryland, under Air Force Rocket Propulsion Laboratory sponsorship which may provide new methods of ascertaining the quality of aged flight motors (Ref. 10). This program consists of several highly instrumented full-scale flight motors which incorporate sensors that are implanted at critical internal locations primarily in the grain and at, or near, the grain/insulator interface. In addition, a number of instrumented analog test specimens which simulate critical portions of the instrumented full-scale motors are also planned, in order to try to establish a meaningful correlation between motor degradation and equivalent degradation experienced by the low-cost analog motor specimens. The ultimate success of this work could provide new, low cost options for verifying and demonstrating extended motor shelf life in future apogee motor programs.

\section{FLIGHT FAILURE SURVEY STUDIES}

Solid rocket motors have inherently high reliability primarily due to the simplicity of design. Nevertheless, seven flight failures have occurred in approximately the last ten years during the burn of an upper-stage solid motor, an apogee solid motor, or a retrorocket solid motor. These flight failures include: (1) Syncom I with a TE-M-375-1 solid, (2) Surveyor IV with a TE-M-364-5 solid, (3) Intelsat II with an SVM-l solid, (4) Scout $151 \mathrm{C}$ with an FW-4S solid, (5) Delta 71 with a TE-M-364-3 solid, (6) Intel sat III with an SVM-2 solid, and (7) Skynet IA with a TE-M-521-1 solid. In most 
instances, motor flight instrumentation was nonexistent or so limited that it was not possible to verify that the solid motor had actually failed. However, the rocket was one of several prime suspects. Although no reliable figures are available, it is believed that these seven failures probably represented a loss in excess of $\$ 100,000,000$.

As a result of these flight failures there was a need to reassess rocket motor design, development and flight usage and to identify methods for reducing the likelihood of future failures. Two companion reliability management studies have been completed recently which examined (1) system environmental and applications aspects and (2) solid rocket motor aspects. Five specific flight failures (see Table 3) were selected for detailed examination in each of the studies. A summary of the objectives, the study approach, and significant findings are as described below.

\section{A. SYSTEM EFFECTS STUDY}

The primary objective of this JPL study was to ascertain whether a common thread could be found between the various failures which could be related to systems or user influences. Cognizant project and technical personnel were contacted and a number of personal visitations made to prime contractors and responsible flight agency offices. Available failure review board reports were reviewed and rocket motor procurement and qualification test requirements were evaluated and compared to motor demonstrated capabilities.

A condensation of significant findings from this study (Ref. 11) are:

(1) There are no fundamental inadequacies between demonstrated motor capabilities and normal user service demands.

(2) A number of unexplained flight failures occurred midway or during the latter portions of the motor burn time when the simultaneous synergistic effects of vibration, acceleration, and thermal (combustion) penetration environments could have contributed to the possibility of a rocket failure. However, there is no direct evidence to support this hypothesis. 
(3) There is some evidence that some of the motors from these programs were not maintained or monitored adequately during ground storage.

(4) In some instances, motors were flown which exceeded specified shelf life. A small sample statistical analysis performed on the combined motors used in the programs studied suggests a strong relationship between possible solid motor flight failures and motor age.

\section{B. APOGEE MOTOR RELIABILITY STUDY}

An apogee motor reliability study was performed by the Stanford Research Institute (SRI) (Ref. 5) under JPL subcontract. Motors to be investigated were the same as those selected for the systems study. The primary objectives were to review each motor history including initial design, development, qualification, motor fabrication and final flight. The study was implemented by an initial study of all pertinent motor documentation. On-site audits were subsequently performed at the Aerojet Solid Propulsion Company, Sacramento, California, at the Thiokol Chemical Company, Elkton, Maryland, and at the United Technology Center, Sunnyvale, California, to review each motor program and to identify possible problem areas.

A condensation of significant findings from the SRI study are:

(1) Each motor contractor has developed a unique combination of design concepts capable of delivery of the required performance with a high degree of reliability.

(2) Each motor contractor provides adequate and strict controls for inert components procured from subcontractors.

(3) Current processing practices (1972) reflect marked improvements over those used during the manufacture of past motors. One example is the reduced moisture allowables and controls currently used for CTPB propellant formulations and case bond liner systems. 


\section{DIAGNOSTIC INSTRUMENTATION}

In the majority of flight failures (see Table 3 remarks), a complete loss of signal prevented an analysis which would ascertain the subsystem which failed or the cause of failure. This is due to the lack of diagnostic instrumentation aboard the satellites. The cost, difficulty of implementation, and limited need for diagnostic data have resulted in the elimination of such engineering instrumentation: however, when failure occurs, the need for diagnostic data is imperative.

An analysis has been conducted at the Jet Propulsion Laboratory to determine the performance, typical cost, and unit characteristic of two instrumentation systems (Ref. 12). One was a continuous real-time design; the second was a hardened $(10,000 \mathrm{~g})$ threshold hybrid design which would have a high probability of data return. The results of the study substantiated that a self-contained independent flight instrumentation module is feasible using state-of-the-art technology and that a common package which could be utilized by many users could be developed.

In order to bound the problem, the capability of the flight instrumentation package was limited to the detection of whether or not the solid motor was the cause of failure and to the identification of probable primary failure modes; however, application of the instrumentation package to other subsystems is possible.

After a review of failure modes, it was determined that measurement of three-axis acceleration, motor chamber pressure, and a limited number of temperatures would be adequate instrumentation. The characteristics of this instrumentation are shown in Table 4 . The key functional and unit characteristics of the two designs are shown in Table 5. Figure 3 illustrates a conceptual design of a hardened diagnostic instrumentation package. The sensors; of course, are external to this package. Table 6 compares the estimated weight, volume, and development and flight costs for the hardened and unhardened designs. 


\section{CONCLUDING RECOMMENDATIONS}

The following conclusions derived from the programs discussed above provide a list of options available to motor suppliers, system prime contractors, flight project offices, and responsible NASA and DOD agencies for implementation on future apogee motor programs. Selective upgrade of future apogee motors can result in increasing satellite cost effectiveness by reducing the potential for future flight failures.

(1) Motor design margins, which were critical in past projects, should be verified at the start of each motor development program by testing, preferably to failure. This is one method of establishing a high degree of confidence in the integrity of the motor beyond that normally afforded by the normally small (and statistically insignificant) development and qualification test program.

(2) More effort should be directed toward monitoring rocket motors after fabrication. Storage and transportation environments should be maintained within prescribed limits; active or passive sensors should be utilized to verify that humidity, temperature, or shock limits have not been exceeded. Adequate detection of propellant-to-insulator case bond separation by conventional radiographic NDT techniques continues to be a problem where the actual separation gap is small; conditioning the motor at low temperature (but within design limits) during the inspection can improve fault resolution. Shelf life of each motor design should be established on the basis of motor design margins, storage conditions, and propellant stability and aging characteristics and not predicated on propellant considerations alone.

(3) Launch operations should be strengthened by providing at least a limited level of motor supplier support during motor inspection and installation at the launch site. Minimal direct rocket motor diagnostic flight instrumentation should be provided for each flight. Chamber pressure and accelerometer transducers will provide meaningful diagnostic data in the event of a flight failure. Development and qualification of a standard solid motor flight 
diagnostic instrumentation package under NASA/DOD agency sponsorship could provide additional incentive for individual flight projects to use such equipment.

\title{
DEFINITION OF ABBREVIATIONS
}

\author{
AIAA American Institute of Aeronautics and Astronautics \\ ATS Applications Technology Satellite \\ CTPB carboxy-terminated polybutadiene \\ DOD Department of Defense \\ EED electroexplosive device \\ ESRO European Space Research Organization \\ FAA Federal Aviation Agency \\ IUS interim upper stage \\ NATO North Atlantic Treaty Organization \\ NDT nondestructive test \\ S\&A safe and arm \\ SRI Stanford Research Institute \\ SVM space vehicle motor \\ Syncom Synchronous Orbit Communications Satellite
}




\section{REFERENCES}

1. Astronautics and Aeronautics, Vol. 11, No. 6, June 1973.

2. Anderson, R., Gin, W., and Kohorst, D., The Syncom I JPL Apogee Rocket Motor, Technical Memorandum 33-143(Revision 1), Jet Propulsion Laboratory, Pasadena, Calif., Sept. 16, 1963.

3. Browne, T., and Jones, J., "Propulsion Technology for Orbital Placement of Synchronous Satellites, "paper presented at 1971 JANNAF Combined Propulsion Meeting, Las Vegas, Nevada, Nov. 1-5, 1971.

4. Eshleman, F., and Edwards, J., "The Design, Development and Testing of a High Performance Apogee Motor, Utilizing a Remote Initiation System, for the Communications Technology Satellite (CTS)," AIAA Paper 73-1174, AIAA/SAE 9th Propulsion Conference, Las Vegas, Nevada, Nov. 5-7, 1973.

5. Martin, P., Failure Analysis of Solid Rocket Apogee Motors, SRI Project 1614 , JPL Contract 953298, Stanford Research Institute, dated September 1972.

6. Anderson, R. G., The Applications Technology Satellite Apogee Rocket Motor: A Summary Report, Technical Memorandum 33-338, Jet Propulsion Laboratory, Pasadena, Calif., Feb. 1, 1970.

7. Menichelli, V. J., and Rosenthal, L. A., Fault Determinations in Electroexplosive Devices by Nondestructive Techniques, Technical Report 32-1553, Jet Propulsion Laboratory, Pasadena, Calif., Mar. 15, 1972.

8. Shafer, John I., "Solid-Propellant Motors for High-IncrementalVelocity Low-Acceleration Maneuvers in Space, "Technical Memorandum 33-528, Jet Propulsion Laboratory, Pasadena, Calif., Mar. 1, 1972.

9. Ray, R. L., "Long-Term Storage Test of a SYNCOM Solid Rocket Motor," in Quarterly Technical Review, Vol. 2, No. 2, Jet Propulsion Laboratory, Pasadena, Calif., July 1972.

10. Status Report, Space Motor Surveillance Program, June 1973-September 1973, Contract No. F04611-73-C-0026, Thiokol Chemical, Elkton, Md., Oct. 15, 1973.

11. Don, J., and Piersol, A., System Effects on the Reliability of Solid Propellant Rocket Motors," Report 900-622, Jet Propulsion Laboratory, Pasadena, Calif., July 1973.

12. Nakamura, Y., Arens, W. E., and Wuest, W. S., Solid Motor Diagnostic Instrumentation, Technical Memorandum 33-656, Jet Propulsion Laboratory, Pasadena, Calif., Dec. 1, 1973. 
Table 1. Estimated apogee motor use through 1990

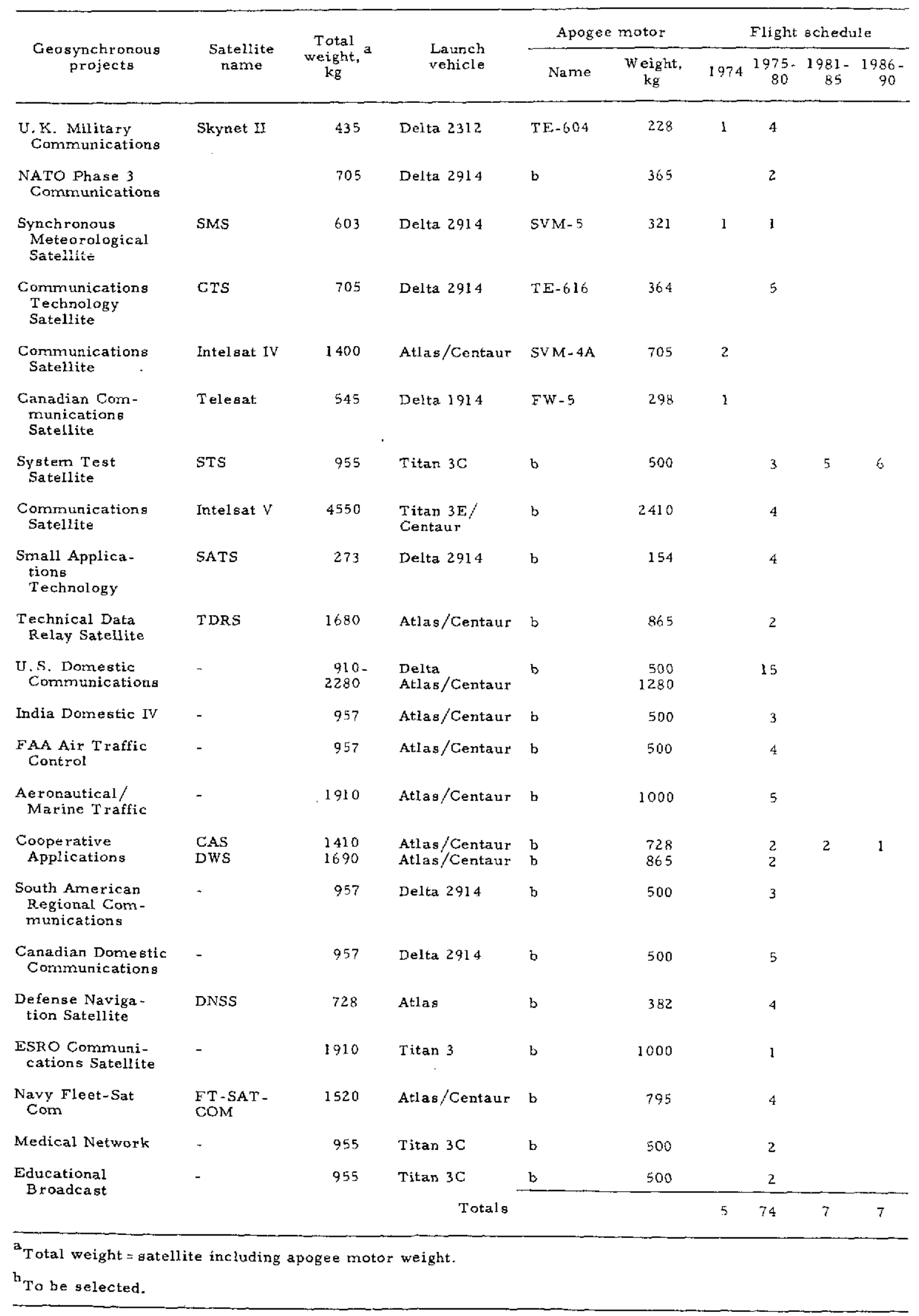


Table 2. Apogee motor reliability design options

\begin{tabular}{lcc}
\hline \multirow{2}{*}{$\begin{array}{c}\text { Rocket } \\
\text { component }\end{array}$} & \multicolumn{1}{c}{ Reliability design options } \\
\cline { 2 - 3 } $\begin{array}{l}\text { Squib or } \\
\text { Initiator }\end{array}$ & Yedundancy & $\begin{array}{c}\text { Design } \\
\text { margins }\end{array}$ \\
Igniter assembly & Yes & Yes \\
$\begin{array}{l}\text { S\&A } \\
\text { Chamber }\end{array}$ & No a & Yes \\
$\begin{array}{l}\text { Chamber insulator } \\
\text { Grain }\end{array}$ & No & Yes \\
$\begin{array}{l}\text { Grain relief boots } \\
\text { Nozzle assembly }\end{array}$ & No & Yes \\
\hline $\begin{array}{l}\text { Electromechanical safe and arm assemblies } \\
\text { provide safety redundancy but do not provide } \\
\text { redundancy from the standpoint of insuring a } \\
\text { successful motor burn. }\end{array}$ & No & Yes \\
\hline
\end{tabular}


Table 3. Selected flight failures

\begin{tabular}{|c|c|c|c|}
\hline Program/vehicle & $\begin{array}{l}\text { Motor designation/ } \\
\text { Contractor }\end{array}$ & $\begin{array}{l}\text { Failure } \\
\text { hypothesis }\end{array}$ & Remarks \\
\hline \multicolumn{4}{|l|}{ Apogee Applications } \\
\hline Intel sat $\mathbb{I} /(\mathrm{F}-1)$ & SVM-1/Aerojet & $\begin{array}{l}\text { Rocket motor aft-end } \\
\text { ingulator and case } \\
\text { failure at }-30^{\circ} \mathrm{F} \text {. }\end{array}$ & $\begin{array}{l}\text { Actual inflight low tem- } \\
\text { perature excursion was } \\
\text { beyond motor design } \\
\text { limits. Failure subse- } \\
\text { quently simulated in } \\
\text { ground tests. }\end{array}$ \\
\hline Intel sat III $/(F-8)$ & SVM-2/Aerojet & $\begin{array}{l}\text { Specific failure mode } \\
\text { not authenticated. }\end{array}$ & $\begin{array}{l}\text { Sudden data dropout; sun } \\
\text { angle data imply motor } \\
\text { anomaly. }\end{array}$ \\
\hline Skynet I/A & $\begin{array}{l}\text { TE-M- 521-1/Thio- } \\
\text { kol }\end{array}$ & $\begin{array}{l}\text { Specific failure mode } \\
\text { not authenticated. } \\
\text { Propellant/insulation } \\
\text { bond failure } \\
\text { postulated. }\end{array}$ & $\begin{array}{l}\text { Sudden data dropout: } \\
\text { Doppler data imply } \\
\text { motor anomaly. }\end{array}$ \\
\hline \multicolumn{4}{|c|}{ Upper Stage Applications } \\
\hline Scout $/ 151 \mathrm{C}$ & $\begin{array}{l}\text { FW }-4 S / \text { United } \\
\text { Technology }\end{array}$ & $\begin{array}{l}\text { Graphite throat } \\
\text { breakup. }\end{array}$ & $\begin{array}{l}\text { One earlier quality con- } \\
\text { trol motor had cracked } \\
\text { throat. }\end{array}$ \\
\hline Delta $/ 71$ & $\begin{array}{l}\mathrm{TE}-\mathrm{M}-364-3 / \text { Thio- } \\
\text { kol }\end{array}$ & $\begin{array}{l}\text { Specific failure mode } \\
\text { not authenticated. } \\
\text { Massive case rupture } \\
\text { postulated. }\end{array}$ & $\begin{array}{l}\text { Breakup of stage and } \\
\text { payload noted; no tele- } \\
\text { metry data during } \\
\text { incident. }\end{array}$ \\
\hline
\end{tabular}

Table 4. Solid motor diagnostic instrumentation characteristics

\begin{tabular}{|c|c|c|c|c|c|}
\hline Signal/instrument & Range & Accuracy & Resolution & $\begin{array}{l}\text { Frequency } \\
\text { response }\end{array}$ & Waveform \\
\hline \multirow[t]{2}{*}{ 3-axis accelerometer } & $\begin{array}{l}0 \text { to } 20 \mathrm{~g} \\
\text { (longitudinal axis) }\end{array}$ & $\begin{array}{l}\leqq \pm 1 \% \\
\text { desirable }\end{array}$ & $\begin{array}{l}< \pm 1 \% \\
\text { desirable }\end{array}$ & $\geqq 2 \mathrm{kHz}$ & Exponential \\
\hline & $\begin{array}{l}\text { D to } 2 \mathrm{~g} \\
\text { (orthogonal axes) }\end{array}$ & $\begin{array}{l}\leqq \pm 5 \% \\
\text { acceptable }\end{array}$ & $\begin{array}{l}< \pm 5 \% \\
\text { acceptable }\end{array}$ & & \\
\hline \multirow[t]{2}{*}{ Chamber pressure } & $\begin{array}{l}\text { Vactum to } \\
6.89 \times 10^{6} \mathrm{Nm}^{-2}\end{array}$ & $\begin{array}{l}\leq \pm 1 \% \\
\text { desirable }\end{array}$ & $\begin{array}{l}< \pm 1 \% \\
\text { desirable }\end{array}$ & $\geqq 5 \mathrm{kHz}$ & Exponential \\
\hline & $\begin{array}{l}\text { (Vacuum to } \\
\text { l000 psia) }\end{array}$ & $\begin{array}{l} \pm 5 \% \\
\text { acceptable }\end{array}$ & $\begin{array}{l}< \pm 5 \% \\
\text { acceptable }\end{array}$ & & \\
\hline Temperature & $\begin{array}{l}255-316 \mathrm{~K} \\
\left(0 \text { to } 110^{\circ} \mathrm{F}\right) \\
\text { prefire, } \\
644 \mathrm{~K}\left(700^{\circ} \mathrm{F}\right) \\
\text { maximum } \\
\text { postignition }\end{array}$ & $\leqq \pm 5 \%$ & $< \pm 5 \%$ & $\geqq 1 \mathrm{~Hz}$ & Exponential \\
\hline
\end{tabular}


Table 5. Functional and unit characteristics of candidate designs

\begin{tabular}{|c|c|c|c|c|}
\hline Design & Telemetry & Environmental & Data characteristics & Advantages \\
\hline \multirow[t]{4}{*}{ Hardened } & $\begin{array}{l}\text { Both real and } \\
\text { non-real-time } \\
\text { coverage }\end{array}$ & $\begin{array}{l}\text { Hardened for } \\
10,000 \mathrm{~g}\end{array}$ & $\begin{array}{l}\text { High response digital } \\
\text { data }\end{array}$ & \\
\hline & $\begin{array}{l}\text { Large tele- } \\
\text { metry per- } \\
\text { formance } \\
\text { margin }\end{array}$ & 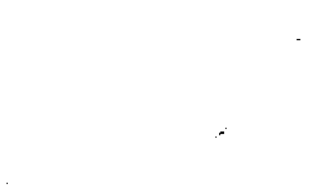 & $\begin{array}{l}\text { Limited threshold } \\
\text { levels } \\
\text { General waveform } \\
\text { Information }\end{array}$ & $\begin{array}{l}\text { Complete diagnostic } \\
\text { coverage under all con- } \\
\text { ditions }\end{array}$ \\
\hline & & & $\begin{array}{l}\text { Timed and untimed } \\
\text { thresholded data }\end{array}$ & \\
\hline & & & Rate-sensitive data & \\
\hline Unhardened & $\begin{array}{l}\text { Continuous } \\
\text { real-time } \\
\text { coverage }\end{array}$ & $\begin{array}{l}\text { Unhardened } \\
\text { package }\end{array}$ & $\begin{array}{l}\text { Limited frequency } \\
\text { response }\end{array}$ & $\begin{array}{l}\text { Smaller } \\
\text { Lighter } \\
\text { Reduced cost }\end{array}$ \\
\hline
\end{tabular}


Table 6. Candidate design properties

\begin{tabular}{lll}
\hline \multicolumn{1}{c}{ Item } & $\begin{array}{c}\text { Hardened } \\
\text { design }\end{array}$ & $\begin{array}{c}\text { Unhardened } \\
\text { design }\end{array}$ \\
\hline Weight & $\begin{array}{l}4.94 \mathrm{~kg} \\
(10.9 \mathrm{lbm})\end{array}$ & $\begin{array}{l}2.45 \mathrm{~kg}(5.4 \\
1 \mathrm{bm})\end{array}$ \\
$\begin{array}{l}0.0097 \mathrm{~m}^{3} \\
\left(0.34 \mathrm{ft}^{3}\right)\end{array}$ & $\begin{array}{l}0.0026 \mathrm{~m}^{3} \\
\left(0.09 \mathrm{ft}^{3}\right)\end{array}$ \\
$\begin{array}{l}\text { Velume } \\
\text { Costs }\end{array}$ & $\$ 240,000$ & $\$ 120,000$ \\
$\begin{array}{l}\text { Flight unit } \\
\text { costs }\end{array}$ & $\$ 46,500^{\mathrm{a}}$ & $\$ 16,500^{\mathrm{a}}$ \\
\hline aproduction lots of $50 \mathrm{to} 100$ units.
\end{tabular}




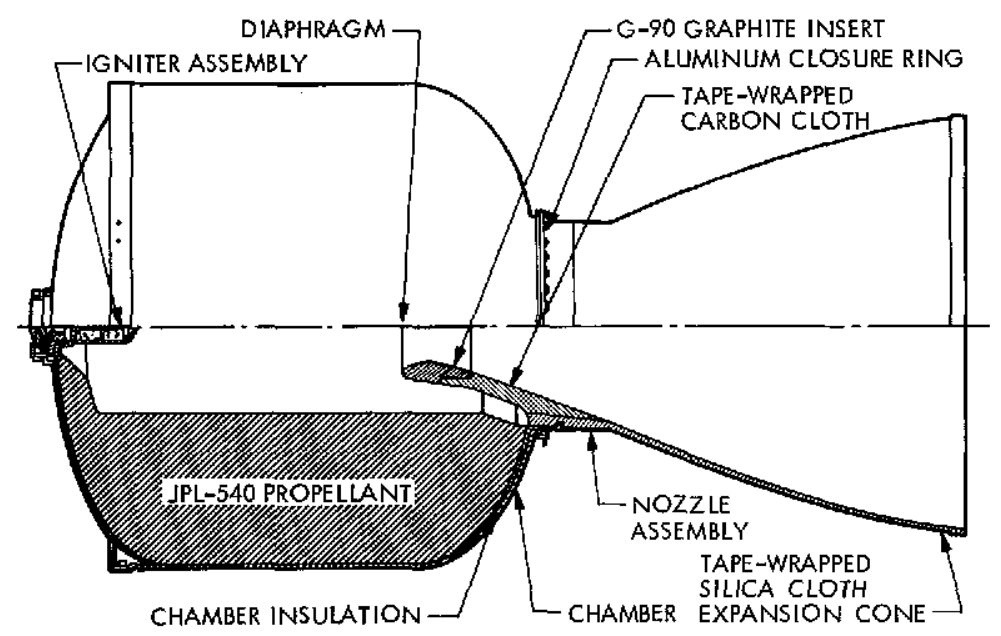

Fig. 1. ATS apogee motor assembly
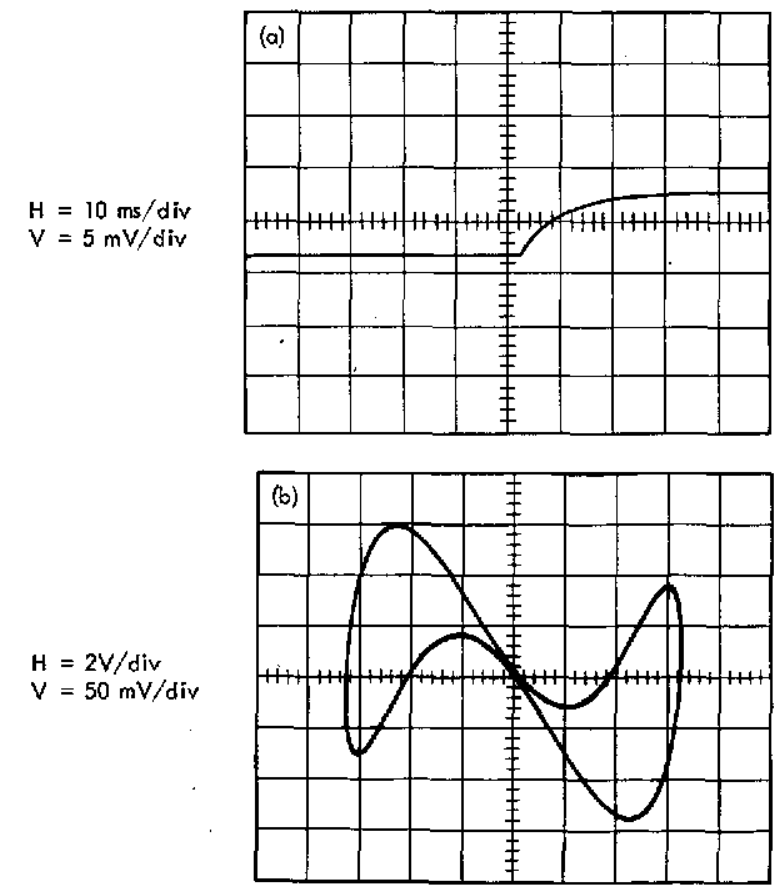

Fig. 2. Oscilloscope display for NDT tests of healthy electroexplosive squibs: (a) transient pulse output, (b) electrothermal follow output 


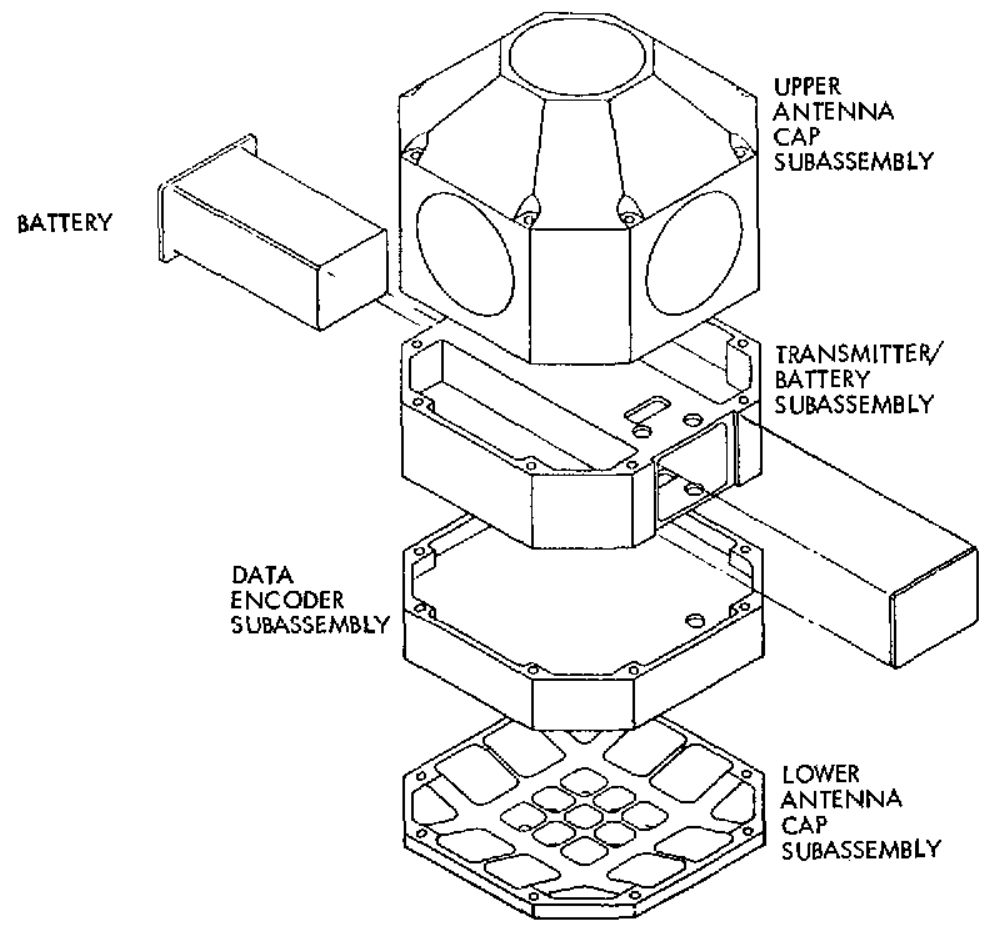

Fig 3. Conceptual design of hardened package 


\section{HOW TO FILL OUT THE TECHNICAL REPORT STANDARD TITLE PAGE}

Make items 1, 4, 5, 9, 12, and 13 agree with the corresponding information on the report cover. Use all capital letters for title (item 4). .Leave items 2, 6, and 14, blank. Complete the remaining items as follows:

3. Recipient's Catalog No. Reserved for use by report recipients.

7. Author(s). Include corresponding information from the report cover. In addition, list the affiliation of an author if it differs from that of the performing organization.

8. Performing Organization Report No. Insert if performing organization wishes to assign this number.

10. Work Unit No. Use the agency-wide code (for example, 923-50-10-06-72), which uniquely identifies the work unit under which the work was authorized. Non-NASA performing organizations will leave this blank.

11. Insert the number of the contract or grant under which the report was prepared.

15. Supplementary Notes. Enter information not included elsewhere but useful, such as: Prepared in cooperation with... Translation of (or by)... Presented at conference of... To be published in...

16. Abstract. Include a brief (not to exceed 200 words) factual summary of the most significant information contained in the report. If possible, the abstract of a classified report should be unclassified. If the report contains a significant bibliography or literature survey, mention it here.

17. Key Words. Insert terms or short phrases selected by the author that identify the principal subjects covered in the report, and that are sufficiently specific and precise to be used for cataloging.

18. Distribution Statement. Enter one of the authorized statements used to denote releasability to the public or a limitation on dissemination for reasons other than security of defense information. Authorized statements are "Unclassified-Unlimited, "U. S. Government and Contractors only," "U. S. Government Agencies only, "and "NASA and NASA Contractors only."

19. Security Classification (of report). NOTE: Reports carrying a security classification will require additional markings giving securify and downgrading information as specified by the Security Requirements Checklist and the DoD Industrial Security Manual (DoD 5220.22-M).

20. Security Classification (of this page). NOTE: Because this page may be used in preparing onnouncements, bibliographies, and data banks, it should be unclassified if possible. If a classification is required, indicate separately the classification of the title and the abstract by following these items with either "(U)" for unclassified, or "(C)" or "(S)" as applicable for classified items.

21 . No. of Pages. Insert the number of pages.

22. Price. Insert the price set by the Clearinghouse for Federal Scientific and Technical Information or the Government Printing Office, if known. 
"TECHNICAL REPORT STANDARD TITLE PAGE

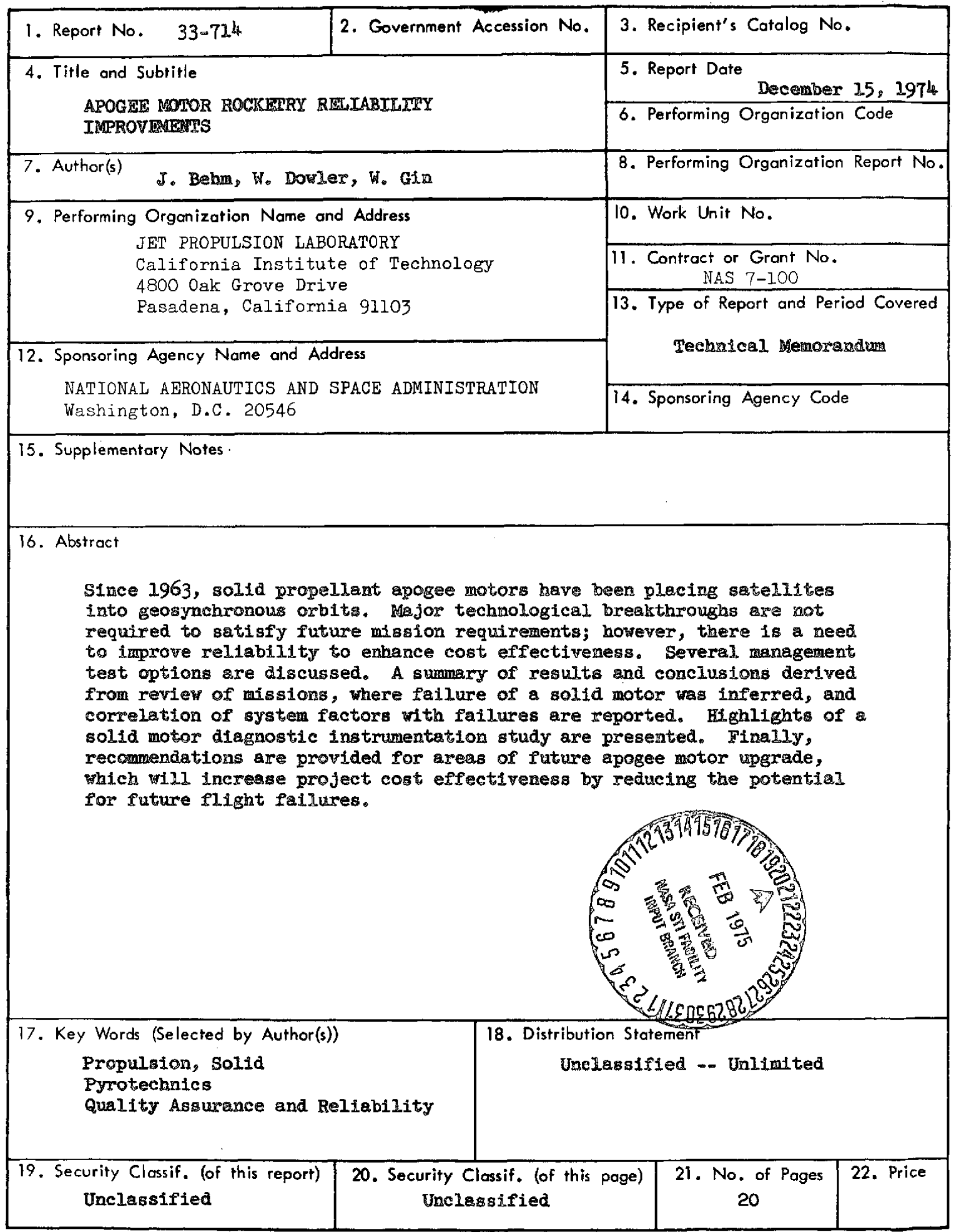

